\title{
RADIATION OF VIRTUAL CATHODE SEQUENCE IN MAGNETIZED RELATIVISTIC ELECTRON BEAM
}

\author{
A.M. Gorban ${ }^{1,2}$, Yu.F. Lonin ${ }^{1}$, A.G. Ponomaryov ${ }^{1}$ \\ ${ }^{1}$ National Science Center "Kharkov Institute of Physics and Technology”, Kharkiv, Ukraine; \\ ${ }^{2}$ V.N. Karazin Kharkiv National University, Kharkiv, Ukraine \\ E-mail:gorban@kipt.kharkov.ua,lonin@kipt.kharkov.ua
}

The numerical simulation method has been applied to investigate the characteristics of radiation from the sequence of two or three virtual cathodes (VC) which are formed in the magnetized plane relativistic electron beam. Between such VC the electric field and beam current feedbacks occur. The spectral electromagnetic radiation characteristics of different vircator configurations and their dependences on the current density and beam energy spread are determined.

PACS: $84.40 . \mathrm{Fe}$

\section{INTRODUCTION PROBLEM DEFINITION}

Dynamics of high-current electron beams with a simultaneous existence of several virtual cathodes (VC) has been considered previously while studying the chaotic behavior of such systems. The main conditions for occurrence of more than one $\mathrm{VC}$ are a significant excess of the beam current over the limiting one [2] and/or a presence of the transverse beam particle dynamics [1, 2]. In any case, a feature of such systems is a localization of all the virtual cathodes in the alone, rather bounded, region. Consequently, the feedbacks between the virtual cathodes are fast-responding.

A purpose of this study is to investigate the system, the feature of which is that two or three VC are spaced along the high-current electron beam propagation current. This is provided by the beam propagation channel profiling. The electron beam moves in the strong ( $>5 \mathrm{kGs}$ ) guiding magnetic field that enables one to exclude from the consideration a transverse particle dynamics. In this system, as distinct from the foregoing one, the beam current and electromagnetic field feedbacks are characterized by essential delays.

\section{DESCRIPTION OF A MODEL}

The model system is a closed region of infinitely extended along the $Z$ axis and having finite sizes along $X$ and $Y$ axis, respectively. A continuous relativistic beam, of a given energy and energy spread, is injected into the system interior (drift chamber) along the $X$ axis. A beam of a finite width (along $Y$ ) is assumed to be completely magnetized and therefore the electron motion is possible only along the $X$ axis. Electromagnetic fields have three components $E_{x}, E_{y}, E_{z}$ (TE-waves). Instantaneous values of the electromagnetic wave field are determined by integrating the Maxwell rotor equations with a correction for a space-charge field.

A numerical method implies "particles in cells" (PIC) with area weighting (CIC model). In more detail the model is described in [3].

\section{MAIN RESULTS}

\subsection{SYSTEM WITH TWO VC}

The diagram of a system with two $\mathrm{VC}$ is presented in Fig. 1. The electron beam having a supercritical current density (higher than the density limited by the space charge) is injected through the grid on the left side of the drift chamber. The beam constantly takes place in the leading magnetic field preventing the transverse particle motion. The first VC is formed in the narrow chamber part. The second VC appears at the input into the wide chamber part, where the current density of the beam passing through the first VC is supercritical too.

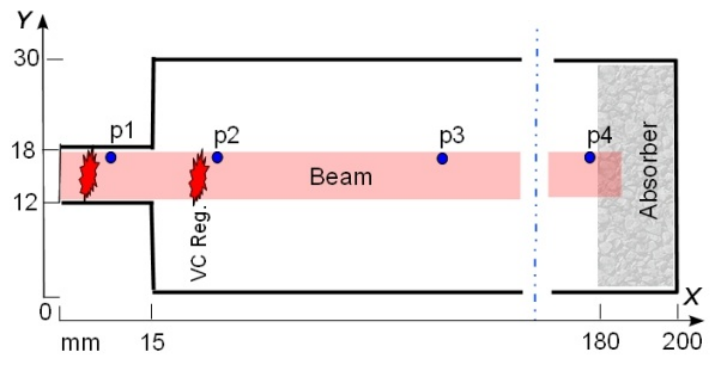

Fig. 1. Diagram of the system with two VC

In Fig. 1 on the right, at the end of the drift chamber, placed is a layer of electromagnetic radiation absorber designed to prevent the reflection. The points of field diagnostics and beam current density are indicated by $\mathrm{p} 1, \mathrm{p} 2, \mathrm{p} 3$, and $\mathrm{p} 4$. The results given below were obtained for the electron beam with the initial energy $E_{0}=300 \mathrm{keV}$ and uniformly distributed energy spread $\Delta E$ of $50 \mathrm{eV}$ and $75 \mathrm{keV}$. The beam width along the $Y$ axis is $0.6 \mathrm{~cm}$. The linear input beam current density $j_{x}$ was about $300 \mathrm{kA} / \mathrm{m}$ (weak supercriticality) and about $2000 \mathrm{kA} / \mathrm{m}$ (strong supercriticality). For a given system geometry two different scenarios of oscillating process development were found.

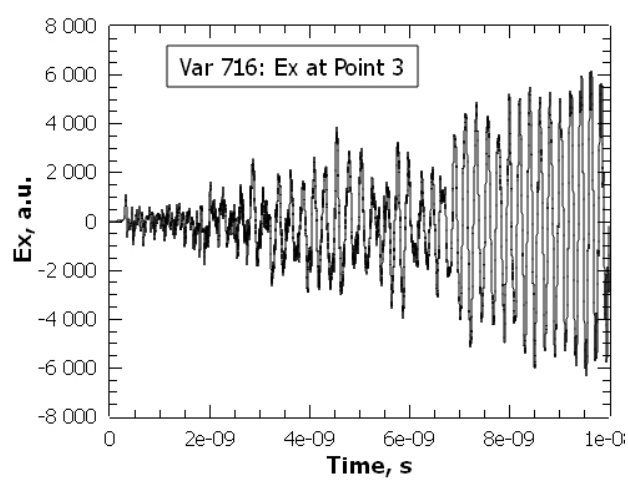

Fig. 2. Amplitude $E_{x}$ for beam $j_{x}=\frac{300 \mathrm{kA}}{\mathrm{m}}$ 
In the case of the weak beam supercriticality the oscillation establishing process can be conditionally divided into three stages (Fig. 2). The first stage (about $3 \mathrm{ns)}$ is characterized by the small field amplitude and wide oscillation spectrum (Fig. 3), where at the system output the frequency corresponding to the first VC oscillations $(25 \mathrm{GHz})$ is almost absent. In the observation point $P 1$ the spectral amplitude of the first VC oscillations is of about $8 \cdot 10^{5}$ a.u. in the scale of diagram magnification (Fig. 3). This may indicate on the first $\mathrm{VC}$ oscillation energy absorption by the part of electrons on the right of this VC.

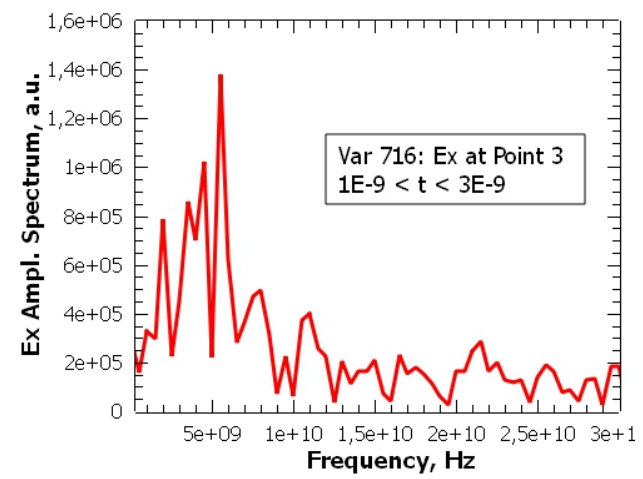

Fig. 3. Amplitude spectrum $E_{x}$ in the first stage

The second stage (from 3 to $7 \mathrm{~ns}$ ) is characterized by the intermittent oscillation mode with the relatively constant average amplitude. The amplitude spectrum $E_{x}$ is presented in Fig. 4

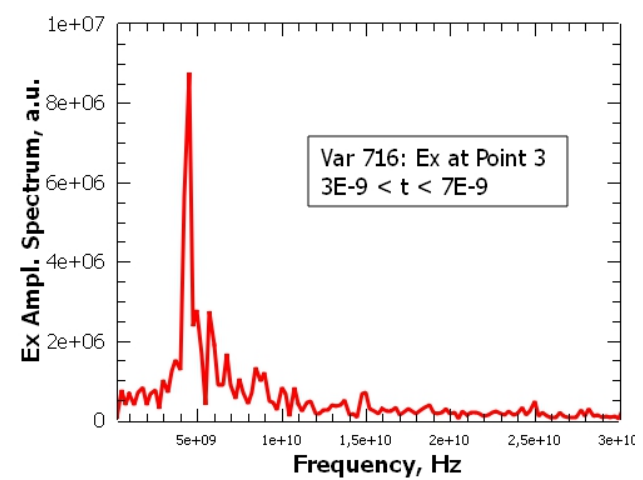

Fig. 4. Amplitude spectrum $E_{x}$ in the second stage

The third stage represents the regular increasing-tosaturation oscillations with the spectrum, shown in Fig. 5, where the first VC contribution is also seen.

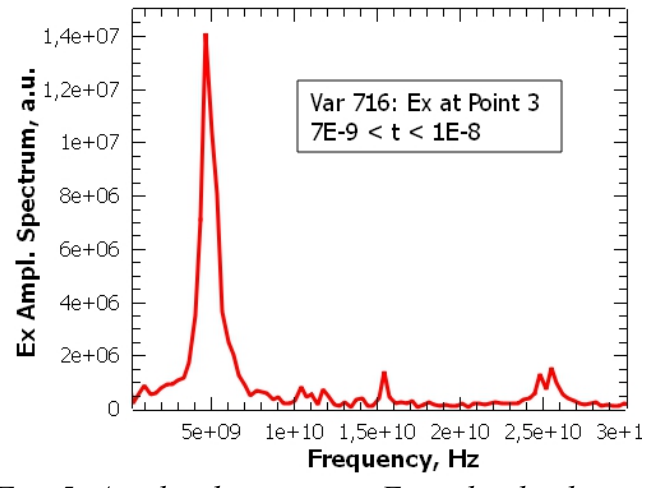

Fig. 5. Amplitude spectrum $E_{x}$ in the third stage

Let us consider the behavior of the number of model beam particles in the system in Fig. 6 .

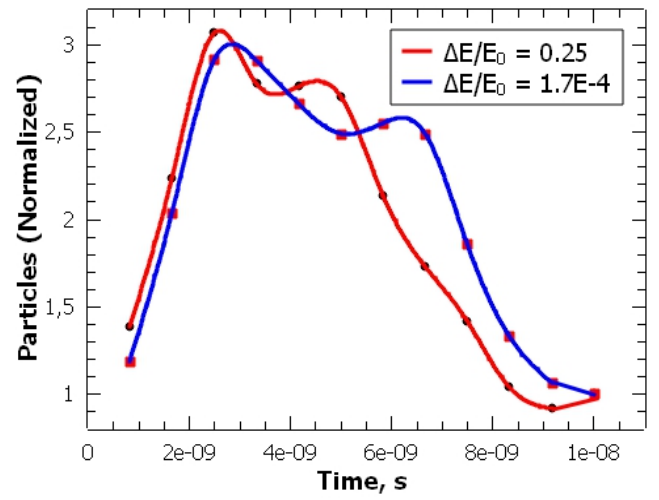

Fig. 6. Number of particles in the system

We can see that the first stage is followed by the quick accumulation of particles so that towards the end the two thirds of particles in the system are trapped and execute oscillations between two VC. In the second stage the number of trapped particles slowly decreases that evidences on the onset of a synchronization phase in the motion of particles and virtual cathode oscillations. And, at last, the third stage corresponds to some synchronizm establishing between the virtual cathode oscillations and dynamics of passed and reflected electrons. As a result the number of particle in the system sharply decreases to the equilibrium one. As is seen from Fig. 6 the beam energy spread increasing to $25 \%$ leads to some acceleration of regular oscillation establishing. At the same time, the common pattern of process development and spectral radiation characteristics remain very close to that shown in Figs. 2-5.

In the event of a strong beam supercriticality the process pattern looks as is shown in Fig. 7. There is a linear regular oscillation amplitude increase to the point of saturation. The radiation spectrum is represented in Fig. 8.

Two explanations of this effect are possible. The first supposes a determining influence of the beam supercriticality when the particle accumulation in the system also takes place. However, the trapped particles have a weak influence on the first VC dynamics which is determined by the injected beam with a higher supercriticality. As a result there the process of the second VC synchronization by the first one occurs.

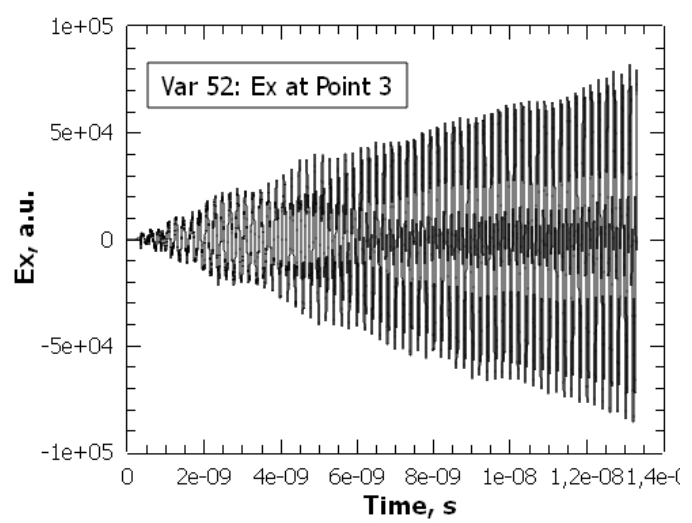

Fig. 7. Amplitude $E_{x}$ for the beam with $j_{x}=\frac{2000 \mathrm{kA}}{m}$ 


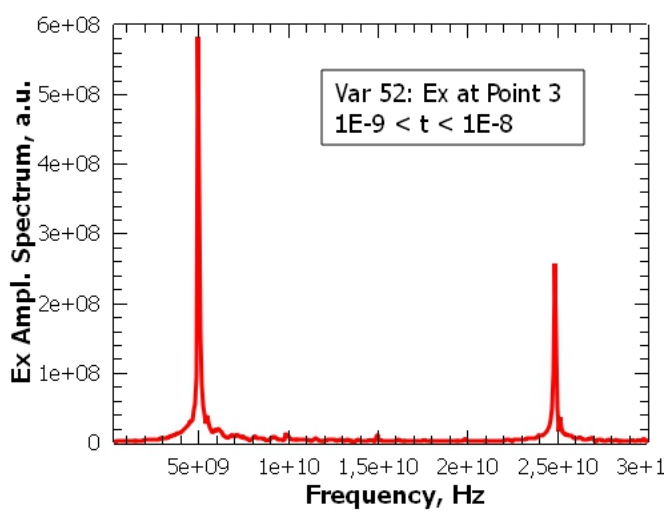

Fig. 8. Amplitude spectrum $E_{x}$ for the beam with

$$
j_{x}=\frac{2000 \mathrm{kA}}{\mathrm{m}}
$$

The second probable explanation supposes oscillations, initially similar to the synchronous oscillations of the both $\mathrm{VC}$ and trapped electrons being dependent on the injected beam current density.

\subsection{SYSTEM WITH THREE VC}

The system with three VC is schematically represented in Fig. 9. As compared to the diagram in Fig. 1 it has only two extensions of the drift chamber instead only one.

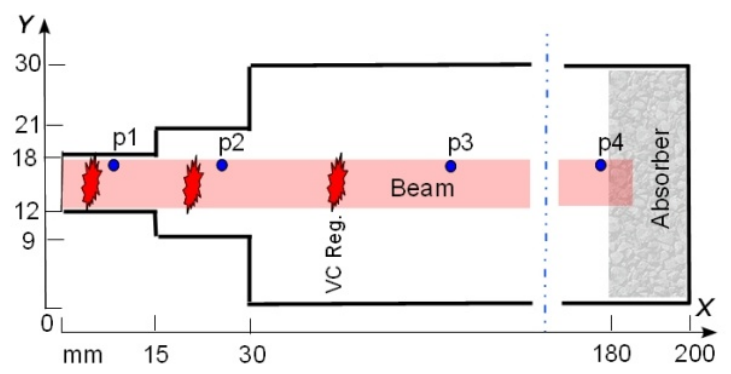

Fig. 9. Diagram of the system with two VC

As expected, the oscillation establishing process in this system is longer (Fig. 10). It is also seen from the time dependence of the particle number in Fig. 11.

In the initial stage (about $7 \mathrm{~ns}$ ) the oscillation spectrum represented in Fig. 12 is similar to the second stage spectrum of the system with two VC (see Fig. 4).

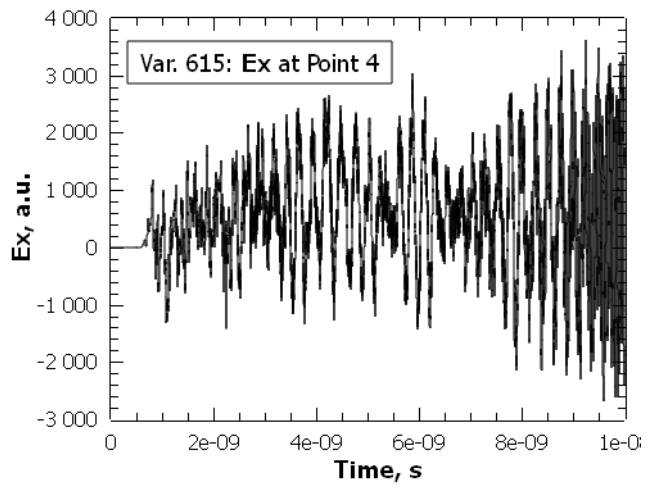

Fig. 10. Amplitude $E_{x}$ for the beam with $j_{x}=\frac{300 \mathrm{kA}}{\mathrm{m}}$

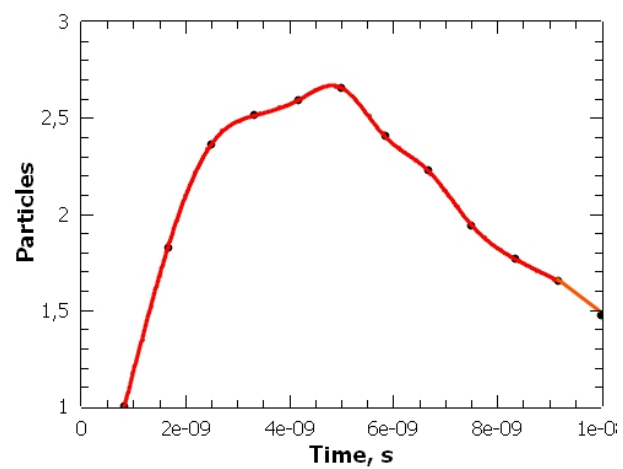

Fig. 11. Particle number in the system with three VC

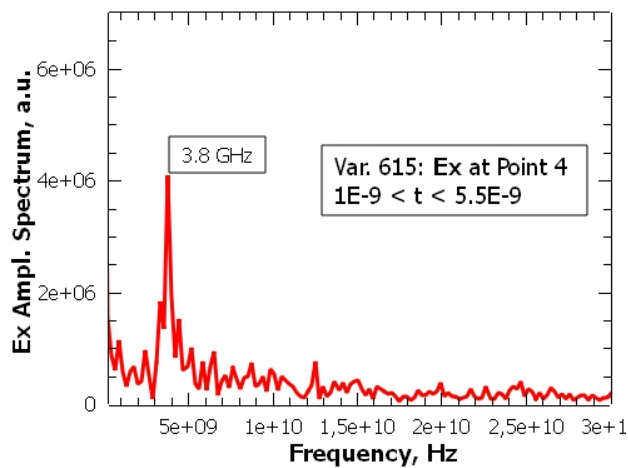

Fig. 12. Amplitude spectrum $E_{x}$ in the initial stage

After reaching a steady state mode the spectral radiation composition strongly depends on the beam current density. The patterns in Figs. 13-15 show the radiation spectrum change with current density doubling.

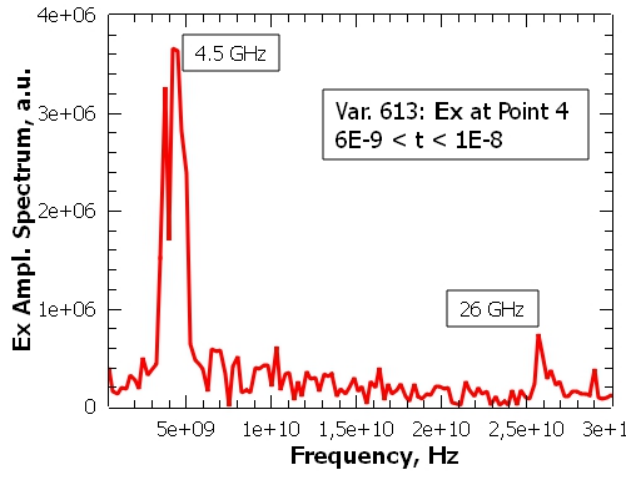

Fig. 13. Amplitude spectrum $E_{x}$ for the beam with

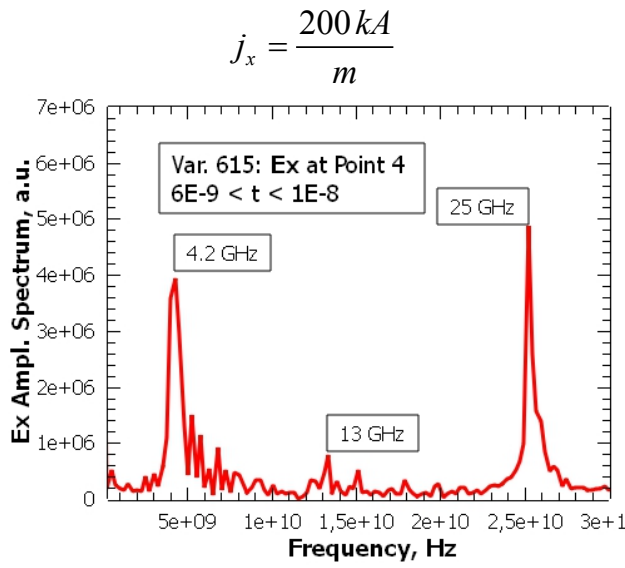

Fig. 14. Amplitude spectrum $E_{x}$ for the beam with

$$
j_{x}=\frac{300 \mathrm{kA}}{\mathrm{m}}
$$




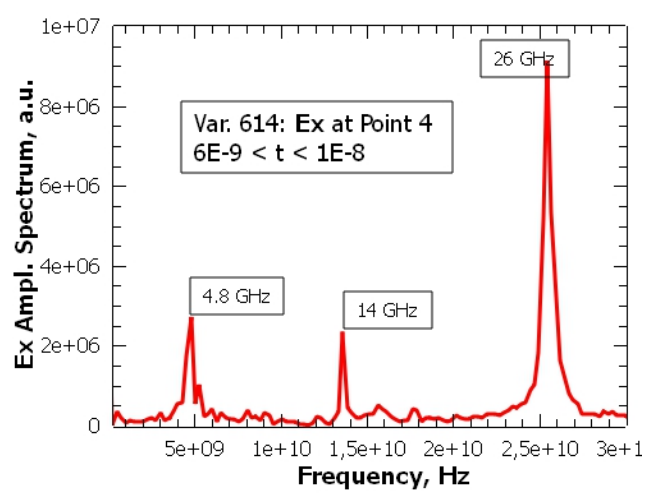

Fig. 15. Amplitude spectrum $E_{x}$ for the beam with

$$
j_{x}=\frac{400 \mathrm{kA}}{\mathrm{m}}
$$

One can see that in the system with three VC the insignificant beam current changes exert significant influence on the spectral radiation characteristics.

\section{CONCLUSIONS}

The results obtained in this study allow the following conclusions.

Magnetized high-current relativistic electron beams with a sequence of spaced VC are the radiation sources having different spectral characteristics.
For the fixed system geometry and particle energy a single parameter determining the radiation spectrum structure is a beam current.

The time of establishing the steady state radiation mode is determined mainly by the lifetime of trapped electrons in the system.

The spectrum structure slightly depends on the beam energy spread.

\section{REFERENCES}

1. V.G. Afinogenov, A.E. Khramov. On the mechanism of chaotic dynamics occurrence in the vacuum microwave oscillator with a virtual cathode // Izvestiya vuzov. Radiofizika. 1998, v. XLI, № 9, p. 1137-1146 (in Russian).

2. Methods of nonlinear dynamics and chaos theory in the problems of microwave frequency electronics. D.I. Trubetskov, A.E. Khramov, A.A. Koronovsky editor. V.2. Nonstationary and chaotic processes. M.: "Fizmatlit", 2009, 384 p.

3. A.M. Gorban', Yu.F. Lonin, A.G. Ponomaryov. Excitation of a flat comb using an electron beam with a virtual cathode // Problems of Atomic Science and Technology. Series "Plasma Electronics and New Methods of Acceleration”. 2018, № 4, p. 67-69.

Article received 22.09.2019

\section{ИЗЛУЧЕНИЕ ПОСЛЕДОВАТЕЛЬНОСТИ ВИРТУАЛЬНЫХ КАТОДОВ В ЗАМАГНИЧЕННОМ РЕЛЯТИВИСТСКОМ ЭЛЕКТРОННОМ ПУЧКЕ}

\section{А.М. Горбань, Ю.Ф. Лонин, А.Г. Пономарев}

Методом численного моделирования исследованы характеристики излучения последовательности из двух и трех виртуальных катодов, образующихся в замагниченном плоском релятивистском электронном пучке. Между такими катодами существует взаимная связь как по электрическому полю, так и по току пучка. Определены спектральные характеристики электромагнитного излучения при разных конфигурациях виркатора и их зависимости от плотности тока и энергетического разброса пучка.

\section{ВИПРОМІНЮВАННЯ ПОСЛІДОВНОСТІ ВІРТУАЛЬНИХ КАТОДІВ У ЗАМАГНІЧЕНОМУ РЕЛЯТИВІСТСЬКОМУ ЕЛЕКТРОННОМУ ПУЧКУ}

\section{А.М. Горбань, Ю.Ф. Лонін, А.Г. Пономарьов}

Методом чисельного моделювання досліджені характеристики випромінювання послідовності двох та трьох віртуальних катодів, що утворюються в замагніченому плоскому релятивістському електронному пучку. Між такими катодами існує взаємний зв'язок як по електричному полю, так і по струму пучка. Встановлені спектральні характеристики електромагнітного випромінювання для різних конфігурацій віркатора та їх залежності від густини струму і енергетичного розкиду пучка. 